\title{
Bacteriological Safety of Water Filters for Dental Units: Evalutation of the Filtration Action against $S$. Aureus and $E$. Coli
}

\section{Antonio Scarano $^{1 *}$, Alberta Greco Lucchina ${ }^{2}$, Camillo Darcangelo ${ }^{3}$, Pierbiagio Stilla ${ }^{1}$, and Tiziano Di Carlo ${ }^{4}$}

${ }^{1}$ Department of Medical, Oral and Biotechnological Sciences and CeSI-Me, University of Chieti-Pescara, Italy

${ }^{2}$ University of Eastern Piedmont, Novara, Italy

${ }^{3}$ Department of Medical, Oral and Biotechnological Sciences, University of Chieti-Pescara, Italy

${ }^{4}$ Department of Dentistry and Maxillo-Facial Sciences, University of Rome "La Sapienza", Italy

*Corresponding author: Antonio Scarano, Department of Medical, Oral and Biotechnological Sciences and CeSI-Me, University of Chieti-Pescara, Italy. E-Mail: ascarano@unich.it

\begin{abstract}
:
Introduction: The safety and control of water for clinical use are of critical importance in dental practice, infact itis needed to cool and irrigate instruments, burs and oral tissues during treatment. Cross - contamination linked to operative procedures is a threat to the health of clinician sad patients with considerable risk of infection. The aim of this study was to evaluate the bacterial filtration of the water of a medical device applied to a dental unit.

Methods: A total of 6 new nano - reticular filters were analysed at different operating times to observe their filtration capability and performances in comparison to 6 used filters.

The sterilizing efficacy of the filter under test was analyzed towards bacterial loads S. Aureus and E.coli, with known titer using two categories of filters: new and used with different operating times verifying the bacterial load present in the outgoing water, since a contaminated 2 litres solution was previously injected. Statistical analysis was performed using the Shapiro - Wilk test and Stat view software from SAS Institute.

Results: The outcome of the evaluation shows that both the used and new filters had highlighted a highly capability of bacterial filtration that attested $99.9999 \%$ in the volume analysed. A statistical difference was found in the bacterial water contamination before and after filtration. $(\mathrm{P}=0.000000)$. No statistical different were observed between new and used filters. $(\mathrm{P}=0.96239)$.

Conclusions: The durability and the efficiency of the filters at different times were positive in controlling cross-contamination and risk of infection during dental procedures.
\end{abstract}

Keywords: Biological safety; Water safety Dental unit; Microbiological tests; Aeruginosa; E.coli.

\section{Introduction}

The microbiological quality of water is a serious ecological problem for public health ${ }^{[1]}$ and for medical devices ${ }^{[2]}$ Dental chair units (DCUs) contain integrated systems providing water to cool hard and soft oral tissues and also the surfaces of the instruments during dental treatment. In fact the microbiological quality of water used in dental units is crucial for the safety of dental personnel and the requirements of dental patients and may relate to cross - infection during the treatment ${ }^{[3]}$ particularly in immune suppressed patients ${ }^{[4]}$. The fungi, Mycobacterium tuberculosis, Pseudomonas aeruginosa, Legionella species, Staphylococcus, Streptococcus are considered opportunistic pathogens in dentistry ${ }^{[5,6]}$. The presence of bacterial and water contamination for DCUs has been shown to be an important cause of cross - infection and cross - contamination ${ }^{[7]}$.

The aspects related to the biological safety of the water used during the dental chair work phases have been brought to the attention of the public health control authorities, in accordance with the new regulations, with particular reference to the new guidelines on the prevention of Legionella issued by the Italian Ministry of Health as early as 2015. In fact, ac-
Received date: February 24, 2018 Accepted date: May 16, 2018 Published date: May 21, 2018

Citation: Scarano, A., et al. Bacteriological Safety of Water Filters for Dental Units: Evalutation of the Filtration Action against $S$. Aureus and E. Coli. (2018) J Dent Oral Care 4(1): 13-16.

Copyright: (C) 2018 Scarano, A . This is an Open access article distributed under the terms of Creative Commons Attribution 4.0 International License. 
Citation: Scarano, A., et al. Bacteriological Safety of Water Filters for Dental Units: Evalutation of the Filtration Action against S. Aureus and E. Coli. (2018) J Dent Oral Care 4(1): 13-16.

cording to the new guidelines, the dentist is responsible not only for the working environment of his surgery but also for the biological safety of the water circulating in the dental unit that feeds the spray syringe, the glass and the rinsing basin and the flushing sprays for the cooling of the rotating or ultrasonic instruments (ultrasonic scaler, air polishing and air abrasion turbines). This is often carried out with water from the mains without bacteriological control or treated with inadequate drainage systems, with the consequent risk of biological contamination of the environment. So if there is legionella, virus or other pathogens in the water supply of the study, the environmental risk of bacterial and / or viral infection occurs when these contaminated water particles are aero solved by introducing these pathogens into the oral cavity of the patient or into the environment surrounding the work area $^{[8]}$. To not mention the further risk of direct blood contagion during working with direct water flushing instruments on a patient undergoing surgical treatments that expose the oral mucosa to bleeding. This risk of contamination can significantly increase during long interventions, due to the continued exposure of the patient and operators to the dispersion of contaminated aerosols in the work place ${ }^{[9]}$. In order to find a suitable solution, capable of sanitizing the incoming water to the dental unit, it was decided to test a medical filtration device specifically designed for the dental unit and currently available on the market. The purpose of this study was to measure the capacity of filtrating. Aureus and E.coli of a medical device of ultra filtration.

\section{Materials and Methods}

A total of 6 new filters and 6 used filters of a medical device of ultra filtration were used in this study. The water filter has a nano - reticular structure $0.05 \mu$ with activated vegetable carbon added as a purifying and anti-odour agent for incoming water upstream of the dental unit, called Koala ${ }^{\circledR}$ filter (ODONTOKOALA Rome, Italy). This dental unit water filter system contains the finest coconut shell based granular activated carbon.

To this end, laboratory tests were performed at two different experimental sites with new and used filters and $S$. aureus and E.coli were taken as indicators for evaluating their efficiency in up to 2 years of operation.

At the Department of Medical, Oral and Biotechnological Sciences of the University of Chieti - Pescara the tests were performed on the bacterial colonies. The sterilizing efficacy of the filter under test was analyzed towards bacterial loads $S . A u$ reus and E.coli, with known titer using two categories of filters: new (table 1) and used with different operating times (table 2) verifying the bacterial load present in the outgoing water, since a contaminated 2 litres solution was previously injected. Two litres of sterile distilled water were filtered to check for any initial contamination of the filtering system (white), then with the same filter the contaminated sample was filtered (continuous physiological solution). The determination of the microbial load at $37^{\circ} \mathrm{C}$ on Plate Count Agar (PCA) was performed: on the white filtrate on the contaminated physiological sample (verification of the initial titer), on the corresponding filter (determined residual microbial). Six trials were performed with, S.Aureus at initial titer of $10^{4}$ and $10^{5} \mathrm{ufc} / \mathrm{ml}$, and six series E.coli at initial titer of respectively $10^{5}$ and $10^{6} \mathrm{ufc} / \mathrm{ml}$. Each series included 6 filtrates of similar contamination samples carried out respectively with a new filter and one already used, for a total of 12 experimental tests. The water for dental use is considered contaminated when waterlines are between 10,000 and 10,000,000 cfu / $\mathrm{ml}$.

Table 1: The average concentration of bacteria isolated before and after 10500 litres filtration.

\begin{tabular}{|l|c|c|c|c|}
\hline \multicolumn{5}{|c|}{ New filters } \\
\hline $\begin{array}{l}\text { Bacterial } \\
\text { strain }\end{array}$ & $\begin{array}{l}\text { Bacterial } \\
\text { suspension } \\
\text { titer (ufc/ml) }\end{array}$ & $\begin{array}{l}\text { Initial sam- } \\
\text { ple titer } \\
\text { (ufc/ml) }\end{array}$ & $\begin{array}{l}\text { White } \\
\text { (ufc/ml) }\end{array}$ & $\begin{array}{l}\text { Residual ti- } \\
\text { ter filtered } \\
\text { (ufc/ml) }\end{array}$ \\
\hline S.Aureus & $2,58 \times 10^{8}$ & $4,1 \times 10^{4}$ & 0 & 0 \\
\hline S.Aureus & $2,53 \times 10^{7}$ & $3,7 \times 10^{5}$ & 0 & 0 \\
\hline S.Aureus & $2,53 \times 10^{7}$ & $3,7 \times 10^{5}$ & 0 & 0 \\
\hline E.Coli & $1,3 \times 10^{9}$ & $1,4 \times 10^{5}$ & 0 & 0 \\
\hline E.Coli & $1,3 \times 10^{9}$ & $1,3 \times 10^{6}$ & 0 & $<1$ \\
\hline E.Coli & $1,3 \times 10^{9}$ & $1,3 \times 10^{6}$ & 0 & $<1$ \\
\hline
\end{tabular}

Table 2: The average concentration of bacteria isolated in the water before and after filtration with used filter.

\begin{tabular}{|l|l|l|l|l|c|}
\hline \multicolumn{7}{|c|}{ Usedfilters } \\
\hline Filter* & $\begin{array}{l}\text { Bacteri- } \\
\text { alstrain }\end{array}$ & $\begin{array}{l}\text { Bacterial } \\
\text { suspen- } \\
\text { siontiter } \\
\text { (ufc/ml) }\end{array}$ & $\begin{array}{l}\text { Initial } \\
\text { sample } \\
\text { titer } \\
\text { (ufc/ml) }\end{array}$ & $\begin{array}{l}\text { White } \\
\text { (ufc/ } \\
\mathbf{m l})\end{array}$ & $\begin{array}{l}\text { Residu- } \\
\text { altiter- } \\
\text { filtered } \\
\text { (ufc/ml) }\end{array}$ \\
\hline Cartridge A & S.Aureus & $2,58 \times 10^{8}$ & $6,6 \times 10^{4}$ & 0 & 0 \\
\hline Cartridge B & S.Aureus & $2,53 \times 10^{7}$ & $4,0 \times 10^{5}$ & 0 & 0 \\
\hline CartridgeC & S.Aureus & $2,53 \times 10^{7}$ & $4,0 \times 10^{5}$ & 0 & 0 \\
\hline Cartridge D & E.Coli & $1,3 \times 10^{9}$ & $1,5 \times 10^{5}$ & 0 & 0 \\
\hline Cartridge E & E.Coli & $1,3 \times 10^{9}$ & $1,5 \times 10^{6}$ & 0 & $<1$ \\
\hline CartridgeF & E.Coli & $1,3 \times 10^{9}$ & $1,5 \times 10^{6}$ & 0 & $<1$ \\
\hline
\end{tabular}

Statistical evaluation: A power analysis was performed using clinical software, freely available on the site http://clincalc. $\mathrm{com} /$ stats/samplesize.aspx, for determining the number of filters needed to achieve statistical significance for quantitative analyses of quantization of bacteria. A calculation model was adopted for dichotomous variables (yes / no effect) by putting the effect incidence designed to caution the reasons $10 \%$ for controls and $95 \%$ for treated. Alpha was setted at 0.6 , Beta at 0.1 and powers a 0.9 . 6 for control.

The optimal number of filters for analysis is 6 tests and

The differences quantitative bacterial before and after water filtration were analyzed by Shapiro - Wilk test. The differences quantitative bacterial filtration between new and used filters was analyzed by Shapiro - Wilk test. A p -value $\leq 0.05$ was considered statistically significant. Statistical analysis was performed using the Statview software from SAS Institute.

\section{Results}

The new and the already used filters after 10500 liters filtration showed an effective retention capacity of the bacterial loads under examination, always recording a residual zero load, even in the presence of high initial contaminant loads $\left(10^{6} \mathrm{ufc} /\right.$ $\mathrm{ml}$ ) with both the bacterial strains used and in any case, demonstrating a reduction of $99.9999 \%$ in the volume analyzed. A sta- 
tistical difference was found in the bacterial water contamination before and after filtration. $(\mathrm{P}=0.000000)$. No statistical different were observed between new and used filters. $(\mathrm{P}=0.96239)(\mathrm{Ta}-$ bles)

\section{Discussion}

In the present study astatistical difference was found in the bacterial water contamination before and after filtration. No statistical different were observed between new and used filters. This result show the efficacy of the filter used towards bacterial loads $S$. Aureus and E. coli. The importance of the data on the safety of the water sanitization systems circulating in the dental unit, is of considerable importance, since it involves both medical and legal aspects of professional responsibility in the workplace. On the basis of the experiments carried out, we can state that the filtering system of the tested Medical Device is an effective barrier, impermeable to the passage of bacteria, including legionella. It has also shown a remarkable seal of its membranes, demonstrating the elimination of bacterial charges, even after some time on used filters.

Therefore, the validation of the system for biological sterilization of water entering the dental chair is the necessary prerequisite to guarantee the safety of its use, in compliance with current regulations.

The device under examination is a $0.05 \mu$ ultra filtration system that places a nonporous physical barrier, impermeable to viruses and bacteria, with a feature demonstrating efficiency and duration equal to a year of work (8000 litres) in safety. With this premise, a series of tests were carried out to measure the effectiveness of the filtering barrier against common bacterial contaminants having equal and inferior dimensions to legionella, in order to exclude the possibility of contamination of the water in transit and exiting the filtering system in question.

In order not to alter the results of the microbial counts, the filters in question were preliminarily disinfected and rinsed and then tested with sterile saline water in order to evaluate their perfect initial sterility, including those already used.

A further observation was made regarding the presence inside the filtering system of activated vegetable carbon. This material is generally used to eliminate odours and chlorine from water, as well as to prevent the formation of algae in water circuits, but at the same time collects the bacterial charge beyond the membranes, for which the efficiency test performed on the filters used represents a significant data on the biological safety of the filter.

In light of the results obtained in the two experiments, the total zeroing by the filtering device of the bacterial and viral charges present in the pre-contaminated water, both at medium and high concentration, is fully demonstrated, for which the sterilizing action of this filter against the bacterial and viral colonies, included legionella, is clearly demonstrated. Moreover, this filtering capacity was maintained even on the used filters, demonstrating a considerable resistance in time of the filtering system and is in accordance with the current guidelines from the Italian Center for Disease Control and Prevention ${ }^{[10]}$.

This longevity of the membranes represents a further significant data on its safety and guarantees its efficiency over time. The filter to purify water should be used in dental practic- es, especially in surgical procedures ${ }^{[11]}$.

From the results obtained it can be concluded that both the new and used filter devices show an absolute filtering capacity towards the $S$. Aureus and E. coli microorganisms.

Conflict of Interest: The authors declare that they have no conflict of interest.

Funding: The present study was self-funded by the authors.

Ethical Approval: This article does not contain any study involving humans or animals. 


\section{References}

1. Liberatore, L., Murmura, F., Scarano, A. Bathing water profile in the coastal belt of the province of Pescara (Italy, Central Adriatic Sea). (2015) Mar Pollut Bull 95(1): 100-106.

Pubmed | Crossref | Others

2. Szymańska, J., Sitkowska, J. Bacterial contamination of dental unit waterlines. (2013) Environ Monit Assess 185(5): 3603-3611.

Pubmed | Crossref $\mid$ Others

3. Pankhurst, C.L., Coulter, W.A. Do contaminated dental unit waterlines pose a risk of infection? (2007) J Dent 35(9): 712-720.

Pubmed |Crossref $\mid$ Others

4. Monarca, S., Garusi, G., Gigola, P.,et al. [Decontamination of dental unit waterlines using disinfectants and filters]. (2002) Minerva Stomatol 51(10): 451-459.

Pubmed $\mid$ Crossref $\mid$ Others

5. Walker, J.T., Bradshaw, D.J., Bennett, A.M., et al. Microbial biofilm formation and contamination of dental-unit water systems in general dental practice. (2000) Appl Environ Microbiol 66(8): 3363-3367.

Pubmed | Crossref $\mid$ Others

6. Schulze-Röbbecke, R., Janning, B., Fischeder, R. Occurrence of mycobacteria in biofilm samples. (1992) Tuber Lung Dis off J Int Union Tuberc Lung Dis 73(3): 141-144.

Pubmed | Crossref $\mid$ Others

7. Coleman, D.C., O’Donnell, M.J., Shore, A.C., et al. Biofilm problems in dental unit water systems and its practical control. (2009) J Appl Microbiol 106(5): 1424-1437.

Pubmed | Crossref | Others

8. Barbeau, J., Tanguay, R., Faucher, E.,et al. Multiparametric analysis of waterline contamination in dental units. (1996) Appl Environ Microbiol 62(11): 3954-3959.

Pubmed |Crossref $\mid$ Others

9. Zhang, Y., Ping, Y., Zhou, R.,et al. High throughput sequencing-based analysis of microbial diversity in dental unit waterlines supports the importance of providing safe water for clinical use. (2017) J Infect Public Health 30251-30254.

Pubmed | Crossref | Others

10. 1Italian Ministry of Health. New guidelines on the prevention of Legionella. 2015.

Pubmed $\mid$ Crossref $\mid$ Others

11. Barbot, V., Robert, A., Rodier, M. H., et al. Update on infectious risks associated with dental unit waterlines. (2012) FEMS Immunol Med Microbiol 65: 196-204.

Pubmed | Crossref | Others

Submit your manuscript to Ommega Publishers and we will help you at every step:

- We accept pre-submission inquiries

- Our selector tool helps you to find the most relevant journal

- We provide round the clock customer support

- Convenient online submission

- Thorough peer review

- Inclusion in all major indexing services

- Maximum visibility for your research

Submit your manuscript at

https://www.ommegaonline.org/submit-manuscript 